UDC 352.4

DOI https://doi.org/10.32782/2524-0374/2021-10/58

\title{
LEGISLATIVE BASIS OF FUNCTIONING OF THE SPHERE OF ENSURING THE RIGHTS OF HEALTHCARE CONSUMERS ${ }^{1}$
}

\author{
ЗАКОНОДАВЧІ ОСНОВИ ФУНКЦІОУВАННЯ СФЕРИ ЗАБЕЗПЕЧЕННЯ ПРАВ \\ СПОЖИВАЧІВ МЕДИЧНИХ ПОСЛУГ
}

Myrhorod-Karpova V.V., Cand. Sc. Law, Deputy Research Director,
Senior Lecturer at the Department of Administrative,
Commercial Law and Financial and Economic Security
Educational and Research Institute of Law of Sumy State University

Educational and Research Institute of Lawo T.V., Cand. Sc. Law,
Shlapk

Associate Professor at the Department of Administrative, Commercial Law and Financial and Economic Security Educational and Research Institute of Law of Sumy State University

\author{
Starynskyi M.V., Dr. Sc. Law, \\ Associate Professor at the Department of Administrative, \\ Commercial Law and Financial and Economic Security \\ Educational and Research Institute of Law of Sumy State University
}

The right to health is a fundamental right of a person and a citizen, and in the legal aspect it acts as a personal inalienable non-property right of everyone and acts as a great social value. The right to medical services, adequate medical care and the effective provision of medical services in general is closely related to the right to health. The implementation of the right to health care in Ukraine is at a low level, according to world official data. These circumstances require the search for new ways out of the crisis in the field of healthcare and protection of the rights and legitimate interests of individuals and citizens in Ukraine. The implementation of world standards in this area is one of the key ways to effectively develop the field and ensure the right to health. With this in mind, in this article we have examined key international regulations, including the Universal Declaration of Human Rights, the Declaration of Helsinki, the Convention for the Protection of Human Rights and Dignity of the Human Being with regard to the Application of Biology and Medicine, Lisbon Declaration, Declaration on the Development of Patients' Rights in Europe, European Charter of Patients, International Covenant on Economic, Social and Cultural Rights, etc. Outlining the main international and European standards of ensuring the rights of healthcare consumers, the article focuses on the current regulatory framework on this issue, identifies its features, shortcomings, gaps and prospects for development. The issue of the prospect of creating a single codified legal act in the field of medical services, taking into account world heritage and international standards for ensuring the rights of healthcare consumers.

Key words: healthcare consumers, patients, doctors, international and European standards, international regulations in the field of medical services.

Право на здоров'я $€$ основоположним правом людини та громадянина, а в юридичному аспекті виступає як особисте немайнове невід'ємне право кожного. Тісно пов'язане з даним правом є право на медичні послуги, належні медичну допомогу та ефективне надання медичних послуг загалом. Реалізація в Україні права на охорону здоров'я відбувається на низькому рівні, про що говорять світові офріційні дані. Ці обставини вимагають пошуку нових шляхів виходу із кризи у сфері надання медичних послуг та захисту прав і законних інтересів особи і громадянина в Україні. Імплементація світових стандартів в даній сфері є одним із ключових шляхів ефективного розвитку сфери і забезпечення права на здоров'я. Нами були досліджені ключові міжнародні нормативно-правові акти, зокрема Загальна декларація прав людини, Хельсінська декларація, Конвенція про захист прав і гідності людини в зв'язку з використанням досягнень біології і медицини, Лісабонська декларація, Декларація про розвиток прав пацієнтів в Європі, Європейська хартія пацієнтів, Міжнародний пакт про економічні, соціальні і культурні права тощо. Окреслюючи основні міжнародні та європейські стандарти забезпечення прав споживачів медичних послуг, в статті зроблено акцент на діючу нормативно-правову базу з даного питання, визначені їі особливості, недоліки, прогалини та перспективи розвитку. Досліджено питання щодо перспективи створення єдиного кодифікованого нормативно-правового акту у сфері надання медичних послуг з урахування світових надбань та міжнародних стандартів забезпечення прав споживачів медичних послуг.

Ключові слова: споживачі медичних послуг, пацієнти, лікарі, міжнародні та європейські стандарти, міжнародні нормативно-правові акти у сфері надання медичних послуг.

Formulation of the problem. The issue of adaptation of domestic legislation to the international standards is one of the key issues today. However, given the implementation of medical reform measures in Ukraine, the provision of medical services is becoming increasingly important every year. After all, with the introduction of reform measures, the real picture in the medical field does not change in the direction of increasing efficiency and effectiveness. Given the lack of an effective mechanism to address the problems that have existed for years in Ukraine, we believe that the implementation of international and European standards can be the impetus for real reform of the sphere.

\footnotetext{
The work is performed under the contract № BF / 24-2021 on the "Implementation of the long-term development plan of the scientific direction "Social Sciences" of Sumy State University" (Economic and mathematical modelling and forecasting, creation of methodological and methodical basis for building a roadmap for healthcare reforms in Ukraine, taking into account the convergent interaction of behavioural, social, economic and legal determinants)
}

Analysis of recent research and publications. There are no comprehensive studies of the implementation of international and European standards in the field of medical services with a thorough analysis of the regulatory framework in Ukraine. At the same time, to one degree or another, this field was studied by such scientists as A.M. Savytska, S.B. Buletsa, O.O. Prasova, S.V. Mykhailov and others.

The aim of the article is to study key international regulations that establish basic international and European standards for the protection of the rights of healthcare consumers and the possibility of their implementation in Ukraine, taking into account the current realities of development and implementation of medical reform.

Presentation of the main material. The adaptation of domestic legislation to the basic principles of EU legislation is one of the main issues of today and one of the key vectors in cooperation between Ukraine and the EU. As early as 1998, after the adoption of the Partnership and Cooperation 
Agreement between the EU, their Member States and Ukraine, the "desire of the Parties to establish close relations based on existing historical ties" was officially declared. The actual adaptation began in 2004 with the adoption and entry into force of the Law of Ukraine "On the National Program for theAdaptation of the Legislation of Ukraine to the Legislation of the European Union". It is the General Program for the adaptation of Ukrainian legislation to EU laws that defines the mechanism for Ukraine to meet the third Copenhagen and Madrid criteria for membership in the European Union. This mechanism includes the adaptation of legislation, the establishment of appropriate institutions and other additional measures necessary for effective law making and law enforcement. The purpose of adaptation of the legislation of Ukraine to the EU laws is to achieve compliance of the legal system of Ukraine with the acquis communautaire taking into account the criteria put forward by the EU to the states intending to join it. Adaptation of Ukrainian legislation to EU laws is a priority component of the process of Ukraine's integration into the European Union, which in turn is a priority of Ukrainian foreign policy [1].

Examining the key aspects of the adaptation of Ukrainian legislation to EU laws, O.Yu. Boiko determines that one of the most pressing issues in this area is the introduction in Ukraine of European standards for ensuring the rights of patients as healthcare consumers. Thus, in his work "International legal concept of patient protection" the researcher points to the historical aspect of this issue and notes that the international protection of the rights of healthcare consumers became most relevant in the middle of the last century, which is closely related to the need to create an effective and efficient mechanism for the protection of human and civil rights and freedoms in all spheres of public life. It was the Universal Declaration of Human Rights, adopted in 1948, that focused on the need for adequate medical protection and healthcare and effective social security and services. These elements are defined as components of the proper provision of the rights and legal freedoms of individuals, which allows to form a sufficient standard of living [2, p. 163].

It should be noted that all modern vectors of development of the sphere of ensuring the rights and interests of patients as healthcare consumers are embedded in different historical stages of declaration. At the same time, in his dissertation study "Contractual obligations in the field of medical services" A.A. Herts argues that the key prerequisite for the emergence oflegal declaration was theneed for clearregulation of the doctor's work and the determination of his / her administrative and legal status. Over time, some aspects of the protection of patients' rights as healthcare consumers have been gradually regulated [3]. For example, in the Declaration of Helsinki in 1964, Article 9 for the first time focused on the procedure for conducting an experiment. It is stated that in order to perform any experiment, the physician is obliged to obtain voluntary informed consent from the participant of the experiment, preferably in writing. Participants in any experiment must be notified that they have the right to opt out of the experiment altogether and may terminate their participation at any time. In 1994 the Declaration on Patient Rights Policy in Europe declared that informed voluntary patient consent is a precondition for any medical intervention. The patient has the right to refuse medical intervention or to suspend it.

The 1997 Convention for the Protection of Human Rights and Dignity of the Human Being with regard to the Application of Biology and Medicine stipulates that any intervention in the field of health may be carried out only with the voluntary and informed consent of the person concerned. Such a person shall be provided in advance with relevant information on the purpose and nature of the intervention, as well as its consequences and risks. The person may at any time withdraw his / her consent without hindrance.

Gradually, in the medical field, the vector of official recognition and declaration of fundamental rights and principles in this field became increasingly relevant. Thus, the Lisbon Declaration of 1981 enshrined key rights in the medical field. Article 3 of the declaration states that the patient as a consumer of medical services has the right to make independent decisions about their health (the patient's right to self-determination), the doctor is obliged to explain to the patient the consequences of the decision. An adult legally competent patient has the right to agree to or refuse any diagnostic procedure or therapy. At the same time, one of the most important international documents that have been developed and adopted in Europe and have made the most significant contribution to the overall development of European legislation regulating the provision of medical services and protection of the rights and legitimate interests of patients is the Amsterdam Declaration or Declaration on the Development of Patients' Rights in Europe of 1994 and the European Patients' Charter of 2002. Researchers note that it was the Declaration on the Development of Patients' Rights in Europe that set out a strategy for promoting patients' rights in Europe, together with effective practical recommendations, and outlined basic principles for patients' rights. The basic rights declared in this document are: the right to information about medical care and how best to use it; the right to consent in the process of receiving medical care; the right to confidentiality and privacy; the right to receive medical care, according to the patient's health, including preventive and curative care [5].

Due to the non-fulfillment of a number of obligations by the EU countries, which directly affected the deterioration of the rights and legitimate interests of healthcare consumers, as well as the qualitatively positive impact of Council of Europe recommendations on the need and priority of civil society participation in decision-making in the medical field and a real increase in the activity of patients and their organizations on the need to regulate this area, a decision was made to adopt a new international instrument that would solve the problems. This document was the European Charter of Patients' Rights adopted in 2002. Representatives of many European countries, including Germany, Ireland, Austria, Italy, Belgium, Great Britain, Spain, Denmark, Greece, etc., took part in the detailed elaboration of the text of this declaration. The European Charter specifies and enshrines 14 basic rights of patients: the right to preventive measures; right to access; the right to information; the right to consent; the right to free choice; the right to privacy and confidentiality of information; the right to respect the patient's time; the right to comply with quality standards; the right to security; the right to access modern achievements; the right to avoid unjustified suffering and pain; the right to individualized treatment; the right to file a complaint; the right to compensation.

Thanks to the European Charter of Patients' Rights, which sets new benchmarks for EU healthcare systems and introduces new standards for patients' rights, several large EU civil society organizations have developed new indicators based on these new standards to assess the performance of the healthcare system and have successfully applied them in the methodology of civil audit in EU countries. Moreover, at the EU level, this work has been carried out repeatedly since 2005, and its materials have been published and made public in the form of reports, which were submitted to the European Parliament in 2005 and 2007 [5].

The main document, which proclaims the basic principles of medical services, is the Declaration on patient-centered medical care. This document focuses on the following principles:

1) the principle of respect, which states that patients and those who provide them with medical care enjoy a fundamental right to healthcare that is patient-centered and guarantees their unique needs, preferences and values, as well as their autonomy and independence;

2) the principle of choice and empowerment: patients have the right and obligation, to the best of their ability 
and preference, to participate as partners in healthcare decisions and those that affect their lives. This requires a healthcare system that responds to patients' needs and provides an adequate choice of treatment options that meet those needs, as well as the encouragement and support of patients and caregivers to achieve the highest possible quality of life. Patient organizations should be able to play a leading role in supporting patients and their families to exercise their right to an informed choice of medical intervention;

3 ) the principle of patient participation in healthcare policymaking, which declares that patients and patient organizations should be able to assume part of the responsibility for health policy-making through real and encouraged participation at all levels and at all stages of decision-making, so that the interests of the patient are given priority in such decisions. They should not be limited to healthcare policies, but should include, for example, social policies that will ultimately affect the lives of patients;

4) the principle of availability and support: patients should have access to the necessary medical care, which means safe, quality and adequate services, treatments, prevention and medical education. It is necessary to ensure the availability of services to all patients, regardless of their condition and socio-economic status. In order for the patient to achieve the most accessible quality of life, healthcare must meet the emotional requirements of patients and take into account non-medical factors such as education, employment and family problems that affect the patient's choice of medical services and the organization of such services;

5) the principle of information: reliable, timely and complete information is necessary so that patients and caregivers can make informed decisions about treatment and the way of living with the disease. Information should be provided in an accessible form in accordance with the principles of medical deontology and taking into account the state of health, language, age, intelligence, abilities and culture of the patient [6].

The level of provision and realization of basic rights and legitimate interests of patients in Ukraine is at an unsatisfactory level. In addition to the absolute disregard for the need to respect the rights of patients and the lack of legal culture of representatives of the medical institutions (medical staff), one of the main reasons for this circumstance is that the domestic legal framework in this area is insufficient and is represented by successors in legislation that can not fully regulate the scope of ensuring the rights of healthcare consumers. Such legislative acts are:

1) The Basic Law of Ukraine - the Constitution of Ukraine, where Article 28 declares that no person may be subjected to medical experiments without his or her free consent; Article 29 declares that every person has the right to liberty and security of person;

2) codified acts - the Civil Code of Ukraine, where part 3 of Article 284 stipulates that the provision of medical care to an individual who has reached 14 years of age is carried out with his or her consent; part 4 of Article 284 - an adult legally competent person who is aware of the significance of his / her actions and can manage them, has the right to refuse treatment. The Criminal Code of Ukraine provides for the possibility of prosecuting a person (criminal) for certain types of crimes in the field of healthcare (failure to provide care to a patient, illegal medical activities, illegal disclosure of medical secrets, etc.). The Code of Ukraine on Administrative Offenses provides for the possibility of prosecution for such offenses as evasion of examination and preventive treatment of persons suffering from sexually transmitted diseases, evasion of medical examination. Issues concerning the procedure for bringing to justice, as well as the procedure for appealing to judicial bodies for protection of rights and their restoration are regulated by procedural legislation, in particular the Criminal Procedure Code of Ukraine, the Civil Procedure Code of Ukraine, the Code of Administrative Procedure of Ukraine.

3) special laws - the Law of Ukraine "Fundamentals of the Ukrainian Health Legislation", where Articles 42 and 43 stipulate that the consent of an informed patient is required for the use of means of diagnosis, prevention and treatment. In the case of a patient under the age of 14 (an underage patient), as well as a patient who has been declared legally incapable in accordance with the procedure established by law, medical intervention is carried out with the consent of their legal representatives. A patient who has acquired full civil capacity and is aware of the significance of his or her actions and can manage them has the right to refuse treatment. Other special legislative acts that will regulate specific issues in the field of medical services and protection of patients' rights are the Law of Ukraine "About donorship of blood and its components" of 23.06.1995, Law of Ukraine "On Insurance" of 07.03.1996,

Levels of consolidation of the rights of healthcare consumers

Table 1

\begin{tabular}{|l|l|l|}
\hline № & $\begin{array}{c}\text { Name of the } \\
\text { consolidation level }\end{array}$ & \multicolumn{1}{c|}{ Examples of acts that correspond to the consolidation levels } \\
\hline 1. & $\begin{array}{l}\text { Universal level } \\
\text { (acts of a declarative } \\
\text { nature and of a } \\
\text { recommendatory } \\
\text { nature for society and } \\
\text { the world) }\end{array}$ & $\begin{array}{l}\text { Universal Declaration of Human Rights (1948) } \\
\text { International Covenant on Economic, Social and Cultural Rights (1966) } \\
\text { Convention on the Rights of the Child (1989) } \\
\text { Convention on the Rights of Persons with Disabilities (2006) } \\
\text { Convention on the Elimination of All Forms of Discrimination against Women (1979) } \\
\text { Convention for the Protection of Human Rights and Fundamental Freedoms (1950) } \\
\text { International Convention on the Elimination of All Forms of Racial Discrimination (1965) } \\
\text { Convention against Torture and Other Cruel, Inhuman or Degrading Treatment or Punishment (1984) }\end{array}$ \\
\hline 2. & $\begin{array}{l}\text { Complex level } \\
\text { (acts regulating } \\
\text { various human rights, } \\
\text { including health } \\
\text { rights) }\end{array}$ & $\begin{array}{l}\text { European Convention on Social and Medical Assistance and its Protocol (1953) } \\
\text { European Social Charter (1996) } \\
\text { Convention for the Protection of Human Rights and Dignity of the Human Being with regard to the } \\
\text { Application of Biology and Medicine (1997) }\end{array}$ \\
\hline 3. & $\begin{array}{l}\text { Specialized level } \\
\text { (act issued by } \\
\text { specialized } \\
\text { organizations) }\end{array}$ & $\begin{array}{l}\text { WHO: } \\
\text { Declaration of Alma-Ata (1978) } \\
\text { Declaration of Lisbon (1981) } \\
\text { WMA (World Medical Association) } \\
\text { Declaration of Geneva (1948) } \\
\text { Declaration of Tokyo (1975). Declaration of Helsinki "Ethical Principles of Medical Research with } \\
\text { Human Participation as an Object of Research" (1964) } \\
\text { International Code of Medical Ethics (1949) }\end{array}$ \\
\hline
\end{tabular}

Source: compiled by the authors on the research basis. 
Law of Ukraine "About organ transplantation and other anatomic materials to the person" of 16.07.1999, Law of Ukraine "About mental health services" of 22.02.2000, Law of Ukraine "About fight against disease of tuberculosis" of 05.07.2001.

4) subordinate legislation - Decree of the President of Ukraine "Physician’s Oath of Ukraine” № 349 of 15.06.1992, the order of the Cabinet of Ministers of Ukraine "On approval of the Concept of health care of Ukraine" № 1313/2000 of 07.12.2000, the order of the Cabinet of Ministers of Ukraine "On approval of the concept of the National Health Program 2020: Ukrainian dimension" № 1164-r of 31.10.2013, the order of the Ministry of Health of Ukraine "On certain issues of organization of state target programs and comprehensive health measures" № 502 of 10.08.2015 [6].

Conclusions. Taking into account all the above, we note that the domestic legislative level of legal regulation of the provision and implementation of the rights of healthcare consumers in Ukraine is at an unsatisfactory level and is characterized by a lack of systematization. The existence of a significant number of subordinate legislation raises the question of the existence of a significant number of borrowings and conflicts. The question of the need to adopt a single normative legal act of a codified nature, which will avoid the above legislative and practical problems, is increasingly raised in medical law. L. V. Krasytska, R. O. Stefanchuk, A. A. Herts make assumptions about the possibility of adopting the Medical Code or the Code of Laws on Public Health in Ukraine or the Code of Biomedicine, etc. [4]. In our opinion, this perspective is quite logical and promising, because there will be a clear disclosure of the content of basic rights of patients in Ukraine, a basic legal act that will fully regulate public relations in the field of consumption of medical services will be formed, the common principles of functioning of this sphere will be defined, the question of formation of contractual relations in the medical sphere and clear fixing of the administrative-legal status of doctors and patients with the only established mechanism of prosecution will be actualized. All these circumstances require the application of effective and efficient foreign experience, which is based on international principles and European standards.

\section{REFERENCES}

1. Про загальнодержавну програму адаптації Законодавства України до законодавства Європейського Союзу : Закон України від 18 березня 2004 року № 1629. URL: https://zakon.rada.gov.ua/laws/show/1629-15\#Text

2. Бойко Ю.Ю. Міжнародно-правова концепція охорони прав пацієнта. Правова позиція. 2018. № 2 (21). С. $162--67$.

3. Герц А.А. Договірні зобов'язання у сфері надання медичних послуг : дис. ... докт. юрид. наук : 12.00.03. Львів, 2016. 421 с.

4. Права людини у сфрері охорони здоров'я : практичний посібник/ за наук. ред. І. Сенюти. Львів : Вид-во ЛОБФ «Медицина і право», 2012.552 с.

5. Україна крізь призму Європейської хартії прав пацієнтів: результати виконання в Україні другого етапу європейських досліджень на відповідність стандартам ЄС з прав пацієнтів. Київ : Видавництво ТОВ «Дизайн і поліграфрія», 2012. 158 с.

6. Практичне право: права пацієнтів (Інтерактивний курс медичного права) : навчальний посібник / Галай В.О., Гречанюк С.К., Сенюта І.Я. та ін. ; за ред. С.Г. Стеценка та А.О. Галая. Київ : КНТ, 2009. 224 с. 